\title{
Effect Of Vitamin-A Supplementation Among 2-5 Years Children In A Slum Area Of Dhaka City
}

\author{
Shah Md. Keramat Ali', Dewan Md. Emdadul Hoquc ${ }^{2}$, Md. Nizamul Hoque Bhuiyan ${ }^{3}$, \\ Md. Moksed Ali Pramanik4.
}

\begin{abstract}
A cross- sectional intervention study was conducted among 30 children of 2-5 years of age, residing in the Agargaon slums of Dhaka City. Majority of the subjects were between 3 \& 4 years. The result showed that supplementation of $V$ it-A bad a noticeable effect on the elevation of retinol level of pre school clildren. Base line mean serum retinol level of the cbildren was $19.70 \pm 5.26 \mu \mathrm{g} / \mathrm{dl}$. After one month of vitamin-A supplementation in the form of biscuits (containing $6 \mu \mathrm{g}$ beta carotene per biscuit), the serwm retinol was raised to $26.66 \pm 5.17 \mu \mathrm{g} / \mathrm{d}$ on an average. Taking $20 \mu \mathrm{g} / \mathrm{dl}$ of serum retinol as deficient level, it was obsenved that initially 21 clildren were in the deficient group. After one month supplementation about $86 \%$ of them were found to bave improved retinol leve/ while 3 children still remained in the deficient group. Beta carotene rich biscuit is a cheap, easy and effective way to increase serum retinol level in cbildren.
\end{abstract}

\section{Introduction}

Vitamin-A deficiency is one of the major nutritional problems in pre school children in developing countries. It was estimated that 500,000 pre school children become blind each year because of vitamin-A deficiency'. In addition, more than 100 million children suffer from vitamin-A deficiency although clinical signs of acute deficiency are not present ${ }^{2}$

In Bangladesh vitamin-A deficiency is a disabling condition in children. Survey reports showed that vitamin-A intake decreased from $1870 \mathrm{IU}$ to $763 \mathrm{IU} /$ person / day between 1962-63 and 1981-82 ${ }^{3}$. Which then increased to 1558 IU / person / day. in 1991-92 ( recommended intake $2013 \mathrm{IU}$ / person / day ).

In 1995-96 survey report it was observed that intake of vitamin-A was $1571.22 \mathrm{IU}^{5}$. Around $1.7 \%$ of children aged between $6-71$ month were suffering from night-blindness. In $1989^{(6,7)}$ more than one million children (6-71 month)

Institute of Nutrition and Food Science (INIS), Dhaka University have visible signs of vit- A deficiency and about half a million suffer from night-blindness. Around 30,000 children (6- 71 month) go blind every year due to chronic vit- $A$ deficiency and almost half of them die within a year of becoming blind coupled with $\mathrm{PEM}^{8}$.

Vitamin A deficiency and its consequences, including blindness, poor growth, severity of infection and death are fully preventable. Govt. of Bangladesh introduced vitamin $-A$ capsule distribution program to combat vit- A deficiency in early 1970, among the targeted children aged 6- 7 months. High potency vit-A capsulc (VAC) coverage among children aged 67 months was $46 \%$ in 1982-83, which decreased to $32.2 \%$ in $1989^{(8)}$ due to weakness of the program management.

As a long-term measure in order to solve vitamin- $A$ deficiency, a food-based approach is of utmost importance. Since vegetable sources are not accessible equally to all the people at all seasons, red palm oil (RPO) which is the richest natural sources of beta- carotene- a pro vitamin$A$, may be an easy solution to this problem. RPO derived from the mesocarp of the oil palm 
(Elias Guinness), although categorized as a saturated fat, can serve as dual role of providing pro-vitamin $A$ and fulfilling the fat energy necds of developing countries. Bangladesh, a poverty stricken devcloping malnourished nation with a population of 128 million, is the most densely populated country of the world. Malnutrition is endemic in this country, more so in urban slums, where people live in a primitive condition with poverty, infections and malnutrition, which contributes to high infant, under five and maternal morbidity and mortality. So, vitamin $\mathrm{A}$ in red palm oil may be used in the diet to reduce the morbidity and mortality incidence rate. Sommer of Indonesia showed $20 \%$ diarrhoeal death could be averted by adding vitamin - $\mathrm{A}$ in treatment of Diarrhea?. Therefore, lowest dictary intake may be of great importance to increase morbidity and mortality related to vitamin $-A$ deficiencies. So the present study has been designed to investigate the impact of dietary intervention of low cost biscuits having $6 \mu \mathrm{g}$ Bcta-carotene of red palm oil (RPO) per biscuit among slum children of $2-5$ years of age with no visible signs of vitaminA deficiency.

\section{Methodology}

The study was carried out using a cross sectional intervention design. Samples were selected on systematic random allocation from a slum of Agargaon at Sher- E Bangla Nagar in Dhaka city. This is a large slum inhabited by about 50,000 people, situated in the North Western area of Dhaka city and adjacent to the local Government and Environmental department office.

The slum houses were numbered and every third house were selected if it has child between 2-5 years. A total of 30 apparently healthy looking children of age 2-5 years were selected. The purpose of the study was explained to the family head and with the permission of the parents a sample of blood was obtained by vein puncture using a baby needle. Serum vitamin- $A$ (recinol) was estimated by modified HPLC method used by Bieri et al ", before and after intervention. A questionnaire was developed to obtain information on age, height, weight, socio- cconomic and other related factors.

Intervention program was made by supplementation of vitamin-A (retinol) enrich biscuits to usual diet among the sample children for a period of 30 days. The goal of the supplement was to provide $80 \%$ retinol equivalent (RE) in the form of biscuit to the children. The composition of one biscuit was: carbohydrate $59.8 \%$, protein $9.1 \%$, Fat $17.1 \%$, and $\beta$-carotene $6 \mu \mathrm{g}$. analysis was done by using SPSS soft ware package. Various statistical tools were used. Mean, standard deviation and Skewness were determined. T-test, chi-square test, Odds ratio and Relative risk were performed to explain the results.

\section{Results}

A total of thirty children aged 2-5 years were studied. Majority of the subjects were between 3 and 4 years of age. Out of 30 children, $36.70 \%$ were male and $63.30 \%$ were female (Table 1). Small values of Skewness of different indicators indicated that the sample indicators were normally distributed and are represented of the population (Table 2). The mean height was $100.47 \mathrm{~cm}$ and the mean weight was $11.63 \mathrm{~kg}$ which were $104.54 \%$ and $76.60 \%$ of the NCHS standard. Considering -2SD cut-off points, WFA, WFH and HFA Z-score data showed that the children were underweight and severely wasted but not stunted. Average monthly household income and family size were Tk.2193.33 \pm 463.07 and $5.23 \pm 1.68$ respectively.

Table 3 shows that the mean increment in blood retinol level over baseline was $6.96 \mu \mathrm{g} / \mathrm{dl}$ (range 6.79-7.45 $\mu \mathrm{g} / \mathrm{dl}$ ). The mean concentration of retinol at baseline had almost equal distribution, though on marginal level. But after intervention it was observed that the children were benefited in increasing resume recinol level. 
Table 4 shows that mean retinol level $(26.66 \pm$ $5.17 \mu \mathrm{g} / \mathrm{dl}$ ) of the children after vitamin-A supplementation was significandy higher $(\mathrm{P}<0.000)$ when compared with baseline mean recinol level $(19.70 \pm 5.26) \mu \mathrm{g} / \mathrm{dl}$ of the children. After intervention 25 children out of 30 had higher retinol level over bascline level (Figure 1).

Table 5 shows that before intervention, the children were underweight as their mean WFA Z-scorc was -2.16 (cut-off point -2 SD). After intervention it was found that the children were not underweight (mean WFA Z-score - 1.91). Mean weight-for-height Z-Score shows that the children were severely wasted (mean -3.14 , cutoff point $<-3 \mathrm{SD}$ ). After intervention it was found that the children were wasted (mean WFA- 2.88 cut-off point $>-2 \mathrm{SD}$ ).

Table 6 shows that prevalence of deficient retinol level $(<20 \mu \mathrm{g} / \mathrm{dl})$ was not equally common in baseline and after intervention $\lambda^{2}=$ $20.07, \mathrm{P}<0.000)$. Odds ratio $(\mathrm{RR}=21.0)$ shows shows that odds of retinol level $(<20 \mu \mathrm{g} / \mathrm{dl})$ of exposure was 21.0 times higher than non exposure ( $>20 \mu \mathrm{g} / \mathrm{dl})$. Initially 21 children were in the deficient group. After one month vitamin-A supplementation only 3 children remained in deficient group. Thus, an $85.7 \%$ improvement in the deficient group was observed.

\begin{tabular}{lcccccc}
\hline Age & \multicolumn{2}{c}{ Male } & \multicolumn{2}{c}{ Fomale } & \multicolumn{2}{c}{ Total } \\
\hline & $\mathrm{n}$ & $\%$ & $\mathrm{n}$ & $\%$ & $\mathrm{n}$ & $\%$ \\
\hline 2 & 0 & 0 & 3 & $10 \%$ & 03 & $10.00 \%$ \\
\hline 3 & 5 & $06.6 \%$ & 5 & $16.66 \%$ & 10 & $33.33 \%$ \\
\hline 4 & 2 & $06.66 \%$ & 9 & $30.09 \%$ & 11 & $36.66 \%$ \\
\hline 5 & 4 & $13.33 \%$ & 2 & $06.66 \%$ & 06 & $20.90 \%$ \\
\hline Total & 11 & 36.70 & 19 & 63.30 & 30 & 100 \\
\hline
\end{tabular}

Table 1: Age and sex distribution of study subjects

\begin{tabular}{|c|c|c|c|}
\hline Indicators & Mesn & San Dev. & Skemnoss \\
\hline Heicht (cm) & 100.47 & 18.30 & -5.40 \\
\hline Woight $(\mathrm{kg})$ & 11.63 & 3.15 & -0.84 \\
\hline Heightelor-3ge Z score & 1.17 & 202 & 0.97 \\
\hline Weightfforage 2 score & -2.16 & 1.44 & -0.18 \\
\hline Woight:for height Z score & -3.14 & 1.80 & 0.04 \\
\hline Monthly household income & 2193.33 & 463.07 & 1.01 \\
\hline Famly size & 5.23 & 1.68 & 0.64 \\
\hline
\end{tabular}

Table 2: Mean standard deviation and skew ness of anthropometric indicators, monthly

household income and family size of the subjects

\begin{tabular}{lcccccc} 
Ag* No. Male Female & $\begin{array}{c}\text { Baso Ino retinol } \\
\text { Mean } \pm \text { SD }\end{array}$ & $\begin{array}{c}\text { Interventon } \\
\text { Mean } \pm \text { SD }\end{array}$ & $\begin{array}{c}\text { Diterence } \\
\mu g / d\end{array}$ \\
\hline 2 & 3 &. & 3 & $20.54 \pm 5.78$ & $27.51 \pm 5.27$ & 6.79 \\
\hline 3 & 10 & 5 & 5 & $19.73 \pm 5.33$ & $26.61 \pm 5.39$ & -6.83 \\
\hline 4 & 11 & 2 & 9 & $19.25 \pm 5.63$ & $26.43 \pm 5.26$ & -7.18 \\
\hline 5 & 6 & 4 & 2 & $19.02 \pm 6.7$ & $26.47 \pm 5.76$ & -7.45 \\
\hline Overal & 30 & 11 & 19 & $19.70 \div 5.26$ & $26.66 \pm 5.17$ & 6.96 \\
\hline
\end{tabular}

Table 3: Retinol levels $\mu \mathrm{g} / \mathrm{dl}$ (before and after) by age and sex

\begin{tabular}{|c|c|c|c|c|c|c|}
\hline Retinal Level & $\begin{array}{l}\text { No. of } \\
\text { Pairs }\end{array}$ & $\begin{array}{c}\text { Nean } \\
\pm S O \\
\end{array}$ & $\begin{array}{l}\text { Increase } \\
\text { Mean dit. }\end{array}$ & $\begin{array}{l}\text { SE of } \\
\text { mean }\end{array}$ & tralue & 2.tal sig \\
\hline Bass ine & & $19.70 \pm$ & & & & \\
\hline & 30 & 5.26 & 8.96 & 0.94 & 7.39 & 0.000 \\
\hline $\begin{array}{l}\text { Atter } 1 \text { mon'h } \\
\text { interventon }\end{array}$ & & $\begin{array}{l}26.66 \\
\pm 5.17\end{array}$ & & & & \\
\hline
\end{tabular}

Table 4: Comparison of retinol level between baseline and after intervention

\begin{tabular}{lcc}
\hline Nutsitonal indicators & Baseline & Aher intervention \\
\cline { 2 - 3 } & Average Z-score & Average Z-soove \\
\hline Waight-tor-age Z score & $-2.16 \pm 1.44$ & $-1.91 \pm 1.12$ \\
& Undenweight & Nomal \\
\hline Weight-tor-height Z score & $-3.14 \pm 1.80$ & $-2.88 \pm 1.32$ \\
& Severely wasted & Wasted \\
\hline
\end{tabular}

Table 5: Comparison of nutritional status between baseline and after intervention by weight-for-age Z-score (WAZ) and weight-forheight Z-score (WHZ) classification

\begin{tabular}{|c|c|c|c|c|}
\hline \multirow{2}{*}{ Serum retinol level } & \multicolumn{2}{|c|}{ Baseline $(n=30)$} & \multicolumn{2}{|c|}{ Aher 1 month $(n=30)$} \\
\hline & No. & $\%$ & No. & $\%$ \\
\hline$\angle 0$ ugld & 21 & 70 & 3 & 10 \\
\hline 220 ugd & 9 & 30 & 27 & 90 \\
\hline
\end{tabular}

Overall improvement after intervention $=85.7 \%$ $\chi^{2}=20.07 \quad \mathrm{P}<0.000 \quad \mathrm{OR}=21.0$

$\mathrm{RR}=3.5$

\section{Discussion}

There is $86.7 \%$ improvement of blood retinol level after intervention along with improvement of nutritional status. During the study, none of the children showed any visible signs of vitamin-A deficiency, but biochemically $70 \%$ of 
the children were deficient $(<20 \mu \mathrm{g} / \mathrm{dl})$ at baseline. After one-month supplementation with biscuits having $6 \mu \mathrm{g} \beta$-carotene each, serum vitamin- $A$ level in all age groups was raised by $6.96 \mu \mathrm{g} / \mathrm{dl}$ and nutritional status of the children by weight-for-age Z-score and Weight-forheight Z-score were improved over the baseline. There was $86 \%$ improvement among vitamin- $A$ deficient children.

Benade ${ }^{11}$ observed that the incorporation of red palm oil (good source of vitamin-A) into snacks and biscuits providing from 50 to $400 \% \mathrm{RDA}$, showed significant improvement in plasma retinol levels in 7-9 years old children after 30 days. We also found increment of blood retinol level after vitamin-A supplementation in the form of biscuits for 30 days. Incorporating red Palm oil as baking fat proved to be a effective way of producing a biscuit fortified with $\beta$. carotenc. This is ideally suited for addressing vitamin-A deficiency in school aged children of South Africa".

Consumption of carotenoid containing food may be as important as dietary intake of preformed vitamin- $A$ in protecting childecn and other members of households from vitamin-A deficiency. This is the important reason for making biscuits for supplementing vitamin-A deficiency group. These biscuits were made by using the naturally existing richest source of beta-carotene, red palm oil.

In our study, where socio-economic conditions and other facilities are poor, $86 \%$ improvement in blood retinol level was observed. Ramakrisna ${ }^{12.13}$ observed in two separate studics in India that vitamin- $A$ supplementation does not reduce common morbidity in children with mild to moderate vitamin-A deficiency in areas where access to health care and immunization are good.

Moderate to severe vitamin-A deficiency is likely to impair normal physical growth but milder stages of deficiency may not have this effect as seen in a study in rural South Asia ${ }^{6}$. Our findings collaborate with this study.
One of the challenges of meeting vitamin- $A$ deficiency is food-based approach, which has been attempted in this study. This study indicated that short-term intervention with popular food item like biscuits, enriched with $\beta$ carotene are acceptable to the children of 2-5 years age group.

\section{Acknowledgement}

We thank MS Carotino Sdn BhD of Malaysia for generous supply of red palm oil and partial cost of estimation of serum retinol. Mr. AKM Fakrul Alam country representative, Malaysian Palm Oil Promotion Council, Dhaka deserves thank for his help.

\section{References}

1. Underwood B.A. Vitamin-A in human nutrition: Public Health Consideration. in sporn MB, Robert AB, Goodman DS (eds). The retinoids: biology, chemistry and medicine, $2^{\text {nd }}$ ed. Raven Press, New York, 1994: pp 211-227.

2. BeatonGH, Martorell R, L'Abbeka et al. Effectiveness of vitamin $A$ supplementation in the control of young child morbidity and mortality in developing countries. Report to the Canadian Agency for International Development, University of Toronto, Toronto, Canada 1992.

3. Ahmed K and Hasan N. Nutrition Survey of Rural Bangladesh 1981-82 Edited by, Inscitute of Nutrition and Food Science, Dhaka University 1983.

4. Akter U Ahmed. Patterns of food consumption and Nutrition nin Rural Bangladesh (Draft), IFPRI, September 1993.

5. Jahan $\mathrm{K}$ and Hosain $\mathrm{M}$. Bangladesh National Nutrition Survey 1995-96, Edited by, Institute of Nutrition and Food Science, Dhaka University 1999. 
6. Helen Keller International and Institute of Public Health Nutrition, Bangladesh Nutrition Blindness study 1982-83.

7. Bangladesh National Food and Nucrition Policy, Govt. Of Pcoples Republic of Bangladesh, 1997.

8. Institute of Public Health Nutrition and UNICEF. Night Blindncss prevention programme Evaluation Report 1989.

9. Sommer A, DjunaediE, LoedenAA ct al. Impact of vitamin-A supplementation on childhood mortality. Lancet, 1986; 1: 116973.

10. Bierri J. G., Tolliver T.T,. Catignani G.L. Simultancous c. Determination of Ltocopherol and retinol in plasma and red cells by high-pressure liquid chromatography, Am. J. Clin. Nutr. 1979;32; 2143-2149.

11. Bende AJS. The use of Red Plam Oil in combating vitamin-A deficiency- a rcview presented in an International Seminar on Nutritional Aspects of Edible Oils, Dhaka 1999.

12. Ramakrishna U, Latham MC, Abel R et al. Vitamin-A supplementation and morbidity among preschool children in South India. Am.J. Clin. Nutr. 1995; 61: 1295-303.

13. Ramakrishna $\mathrm{U}$, Latham $\mathrm{MC}$, abel $\mathrm{R}$ et al. Vitamin-A supplementation Does Not Improve Growth of Preschool Children: $\mathrm{A}$ Randomized Double blind Field Trial in South India. J. Nutr. 1995; 123: 202-211 